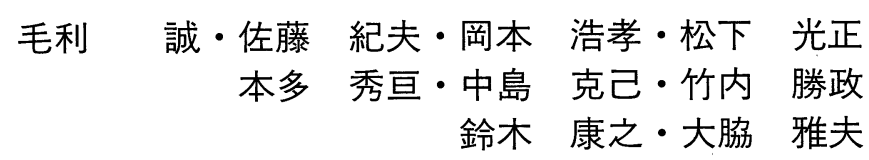

\title{
DEVULCANIZATION CONDITION AND MECHANICAL PROP- ERTIES OF REVULCANIZED RUBBER FOR EPDM
}

Makoto MOURI, Norio SATO, Hirotaka OKAMOTO, Mitsumasa MATSUSHITA (TOYOTA CENTRAL R \& D LABS., INC., 41-1, Aza yokomichi, Oaza Nagakute, Nagakute-cho, Aichi-gun, Aichi, 480-1192 JAPAN)

Hidenobu HONDA, Katsumi NAKASHIMA, Katsumasa TAKEUCHI (TOYODA GOSEI CO., LTD., 30, Nishinomachi, Kitajima-cho, Inazawa-city, Aichi, 492-8411 JAPAN) Yasuyuki SUZUKI, Masao OWAKI (TOYOTA MOTOR CORPORATION, 1, Toyota-cho, Toyota-city, Aichi, 471-8572 JAPAN)

Continuous devulcanization by shear flow stage reaction control technology has been developed. In this technology, it is very effective to give high shear strain to vulcanized rubber under high internal pressure. Using adequate screw geometry and alignment based on this concept, devulcanization can proceed continuously. Properties of devulcanized rubber depend on reaction temperature, screw rotation and addition of devulcanizing agent and process oil. Under adequate reaction temperature and screw rotation, devulcanization can proceed without devulcanizing agent and process oil. Revulcanized rubber obtained by this condition shows excellent mechanical properties nearly equal to virgin ones. Furthermore, mechanical properties of revulcanized rubber can be controlled by addition of devulcanizing agent and process oil.

(Received on May 14, 1998)

Key Word : Recycle, Vulcanized rubber, Shear flow stage reaction control technology, Devulcanization, EPDM

\section{1. 緒言}

ゴム再生技術として，せん断流動場反応制御技 術により加硫ゴムを短時間で連続的に再生する技 術を先報に提出した ${ }^{1)}$. 本技術では，二軸スクリ ユからなる連続処理方式のせん断流動場反応槽を

†本報を「せん断流動場反応制御技術によるゴムの連続再生 (第 2 報)」とする.
用いた脱硫反応処理において, 硫黄加硫 EPDM の硫黄架橋点を選択的に切断して，高品位な再生 ゴムを連続的に得ることが可能となった。この脱 硫反応処理によって得られる再生ゴムの特性は, スクリュ形状, 処理温度, スクリュ回転数等に依 存し，最適な条件での処理により，得られた再生 ゴムの加硫特性, 成形性, 力学特性は新材とほぼ 同等とすることができた。本論文では，脱硫原応 
毛利 誠・佐藤 紀夫 · 岡本 浩孝 - 松下 光正 - 本多 秀亘 - 中島 克己

Table 1 Devulcanizing agents

\begin{tabular}{l|l}
\hline 1.Sulfur substitution reaction & 2.Nucleophilic reaction \\
\hline Diphenyldisulfide & Triphenylphosphine \\
Ditolyldisulfide & Tributylphosphine \\
Dibutyldisulfide & Triphenylphosphite \\
Dixylyldisulfide & Tributylphosphite \\
Cysteine & Tributylphosphineoxide \\
Thiophenol & Trimethylsulfonium lodide \\
Cystine & Tetrabutylammonium Bromide \\
\hline 3.Radical reaction & 4.Others \\
\hline Phenylhydradine $+\mathrm{FeCl}_{2}$ & Benzoic acid \\
Azoisobutylonitrile & Phenol \\
Benzoylperoxide & Maleic acid \\
Dicumylperoxide & Tartaric acid \\
& Phospholic acid \\
\hline
\end{tabular}

処理に与える上記の条件の影響を明らかにするこ とを目的として，脱硫反応条件と再生ゴムの特性 を詳細に検討した結果について述べる。

\section{2. 実験}

\section{1 試料}

実験には先報と同様の粉砕した硫黄加硫 EPDM を用いた ${ }^{1)}$.この加硫ゴムの初期特性は, 引張強さが $10.2 \mathrm{MPa}$ ，破断伸びが $410 \%$ で有効 網目鎖濃度は $9.0 \times 10^{-5} \mathrm{~mol} / \mathrm{cm}^{3}$ である. Table 1 に示した分解剂としての試薬は市販品を精製せ ずにそのまま使用した。再生オイルとしてプロセ スオイル(出光石油侏製のダイアナプロセスオイ ル PW-380)をそのまま使用した。

\section{2 分解㓮の検討}

せん断流動場反応槽を用いた脱硫反応処理を行 う前に，まず予備検討として，ラボプラストミル を用いてゴムの脱硫反応に有効な分解剂の検討を 行った。粉砕ゴム $40 \mathrm{~g}$ に分解剂 $2 \mathrm{~g}$ と再生オイ ル $12 \mathrm{~g}$ を加えたものを試料とした。この試料を ラボプラストミルで混練して脱硫反応を行い，口 一ターに作用するトルクの時間変化を測定し，そ のトルク変化の様子から分解剤の効果を判断し た。混練条件は温度が $200^{\circ} \mathrm{C}$ ，スクリュ回転数が $120 \mathrm{rpm}$ である.

\section{3 せん断流動場反応槽によるゴムの脱硫反 応処理}

脱硫反応処理には先報と同様の二軸スクリュか らなる連続処理方式のせん断流動場反応槽を使用
した1). 脱硫反応実験では，加硫ゴム粉砕物に所 定量の分解剂と再生オイルを添加して 24 時間以 上室温で放置した試料を反応槽に一定速度で供給 し，混練しながら脱硫反応を行い，ヘッド部より ストランド状の再生ゴムを得た。再生ゴムは冷却 水槽を用いて水冷した後にストランドカッターに より切断しペレット状とした. Table 2 に実験機 を用いた処理条件を示す. No. 1 11 は処理温度, №.12 23 は分解剂/再生オイルの添加の有無およ び添加量, No.24〜30 はスクリュ回転数の影響に ついての検討である。

\section{4 再生ゴムの評価}

再生ゴムのムーニ一粘度, ゲル分率，ゲル成分 の有効網目鎖濃度，ゾル成分の分子量分布を先報 と同様の方法で測定した1).

\section{5 再加硫ゴムの力学特性の評価}

再加硫ゴムの力学特性も先報と同様の方法で測 定した ${ }^{1)}$.

\section{3.結果および考察}

\section{1 分解剤の検討}

せん断流動場反応槽を用いたゴムの脱硫反応処 理検討において，分解剂の添加効果を調べる際に 使用する試薬を，ラボプラストミルを用いた検討 により選定した。使用する分解剂としては，ゴム の硫黄架橋点と選択的に反応すること，反応活性 が高いことが必要である，ゴムの硫黄架橋点を切 断する反応機構としては，ゴムの硫黄架橋点と低 分子硫黄化合物との交換反応により架橋点を切断 
Table 2 Devulcanization conditions

\begin{tabular}{|c|c|c|c|c|}
\hline Test No. & $\begin{array}{l}\text { Devulcanizing agent } \\
(\mathrm{phc})\end{array}$ & $\begin{array}{l}\text { Process oil } \\
\text { (phc) }\end{array}$ & $\begin{array}{c}\text { Temperature } \\
\left({ }^{\circ} \mathrm{C}\right)\end{array}$ & $\begin{array}{c}\text { Screw rotation } \\
(\mathrm{rpm})\end{array}$ \\
\hline 1 & 0 & 30 & 250 & 150 \\
\hline 2 & 0 & 30 & 300 & 150 \\
\hline 3 & 0 & 30 & 350 & 150 \\
\hline 4 & 3 & 30 & 250 & 150 \\
\hline 5 & 3 & 30 & 300 & 150 \\
\hline 6 & 3 & 30 & 350 & 150 \\
\hline 7 & 0 & 0 & 270 & 250 \\
\hline 8 & 0 & 0 & 300 & 250 \\
\hline 9 & 0 & 0 & 290 & 350 \\
\hline 10 & 0 & 0 & 310 & 350 \\
\hline 11 & 0 & 0 & 330 & 350 \\
\hline 12 & 0 & 0 & 300 & 350 \\
\hline 13 & 1 & 0 & 300 & 350 \\
\hline 14 & 0 & 10 & 300 & 350 \\
\hline 15 & 1 & 10 & 300 & 350 \\
\hline 16 & 0 & 0 & 300 & 120 \\
\hline 17 & 3 & 0 & 300 & 120 \\
\hline 18 & 0.5 & 30 & 300 & 120 \\
\hline 19 & 1 & 30 & 300 & 120 \\
\hline 20 & 3 & 30 & 300 & 120 \\
\hline 21 & 0 & 50 & 300 & 120 \\
\hline 22 & 1 & 50 & 300 & 120 \\
\hline 23 & 3 & 50 & 300 & 120 \\
\hline 24 & 0 & 0 & 300 & 250 \\
\hline 25 & 0 & 0 & 300 & 280 \\
\hline 26 & 0 & 0 & 300 & 340 \\
\hline 27 & 0 & 0 & 300 & 420 \\
\hline 28 & 0 & 0 & 300 & 100 \\
\hline 29 & 0 & 0 & 300 & 200 \\
\hline 30 & 0 & 0 & 300 & $\overline{400}$ \\
\hline
\end{tabular}

phc : parts per hundred compound

する硫黄交換反応，求核原子をもつ化合物の硫黄 架橋点に対する反応性を利用する求核反応，ラジ カルを発生する化合物を添加し，発生したラジカ ルと硫黄架橋点との反応を利用するラジカル反応 等が考えられる。このような反応機構および既に 提案されている分解剂 ${ }^{5-10)}$ を参考にして Table 1 に示す化合物を検討した. 混練過程におけるト ルク変化曲線の例を Fig. 1 に示す。混練の初期 では，ゴムは粒状でありローターにかかるトルク は小さいが，脱硫反応が進行すると粒状のゴムは 粘性のある可塑体へと変化して全体が一つの塊状
となり，ローターにかかるトルクが急激に上昇す る。このトルク上昇までの時間が短いほど分解剤 の効果が高いと判断した．硫黄交換反応による分 解剂は全般的に効果が高く, 特にジフェニルジス ルフィド，チオフェノール等が有効であった. 求 核反応による分解剂ではリン化合物の効果が高 く,トリフェニルホスフィンやリン原子に電子供 与性の置換機を有する要リン酸トリフェニル, 覀 リン酸トリブチルが有効であった.ラジカル反応 およびその他の分解剤はいずれもトルクの上昇が 見られなかった．以上の検討のなかではジフェニ 


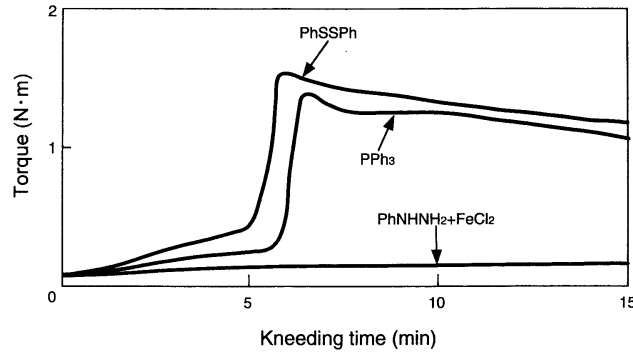

Fig. 1 Torque change curve during devulcanization

ルジスルフィドの効果が最も高く，分解剂の添加 効果を調べる場合に使用した。

\section{2 スクリュ形状の検討}

ゴムの脱硫反応を連続的に行うためには，せん 断流動場反応槽のスクリュ形状が重要な因子とな る。この技術に使用した反応槽のスクリュはセグ メント方式であり，スクリュ形状を目的に応じて 自由に設計することができ，これにより反応槽内 の充満率，ゴムの通過時間，内部ゴム圧力，混練 力およびせん断力を制御することが可能である. せん断流動場反応槽を用いてゴムの脱硫反応を連 続的に進行させるには，ゴムを短時間で脱硫反応 処理温度まで加熱すること, 反応速度を向上させ ること，反応時間を確保することが重要であり， このような考え方に基づきスクリュ形状の設計を 行った．今回の検討では反応槽のスクリュにゴム を微粒化して脱硫反応温度まで加熱するゾーン と，ゴムの脱硫反応を行うゾーンを設定した．微 粒化ゾーンでは約 $5 \mathrm{~mm}$ 角のゴムをスクリュの せん断力により微粒化して圧縮し，短時間で脱硫 反応温度まで加熱しで次の脱硫反応ゾーンへ送り 込む. 脱硫反応ゾーンでは逆送りニーディングデ イスクを適切に配置してゾーン内の充満率を高め てゴムを高度に圧縮し，ゴムに作用する静水圧を 向上させた。この圧力が高い状態で，ゴムに高い せん断変形を与えることが脱硫反応速度の向上に 有効であった．また，充満率の向上により反応ゾ ーン内の通過時間が長くなり，反応時間の確保が 可能となった. 以上のような検討に基づいて脱硫 反応ゾーンのスクリュ形状を適切に設計すること により，外見上ストランド表面の滑らかな再生ゴ ムを連続的に得ることが可能となった。

\section{3 脱硫反応条件の検討}

\subsection{1 処理条件と再生ゴムの特性 せん断流}

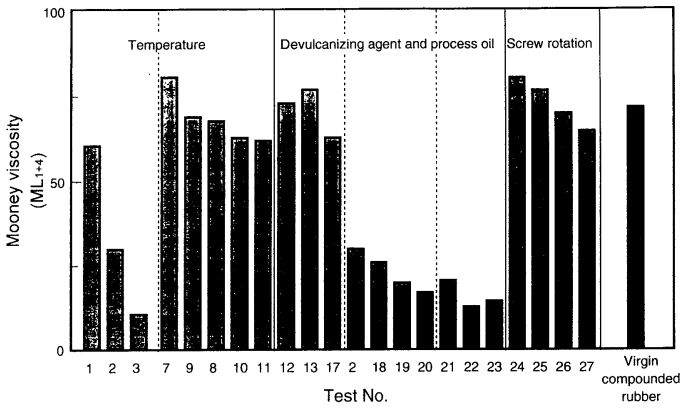

Fig. 2 Mooney viscosity of devulcanized rubber

動場反応槽の処理温度, 分解剂/再生オイルの添 加の有無および添加量, スクリュ回転数の各項目 について検討を行った. Table 3 に得られた再生 ゴムのムーニ一粘度，ゲル分率，ゲル成分の有効 網目鎖濃度を示す。このなかからムーニ一粘度に ついてまとめて Fig. 2 に示す。ムーニー粘度は 処理温度とともに低くなり，高温では非常に低い 值となった. 分解剂/再生オイルを添加しない系 で詳細に処理温度について検討したところ， $300^{\circ} \mathrm{C}$ 前後の処理で新材とほぼ同等の粘度となっ た。次に処理温度を一定にして分解剂/再生オイ ルの影響を検討した．添加量とともに粘度は低く なり，特に再生オイルの添加により粘度は大きく 低下した。 ただし再生オイルを 30 重量部以上添 加しても, 粘度の変化はほとんどみられなかっ た. 再生オイルの添加が少量の場合, 分解剂の添 加により粘度は低下したが, 再生オイルの添加量 が多い場合は，分解剂を添加しても粘度は若干低 下するだけであった。またスクリュ回転数にも若 干影響され，回転数とともに粘度は低下寸る傾向 にあった。

トルエンを用いた膨潤試験の結果において, 再 生ゴムはトルエンに可溶なゾル成分と不溶なゲル 成分の混合物であった。 トルエンに不溶なゲル成 分量およびゲル成分の有効網目鎖濃度を Fig. 3 に示す．ゲル成分量およびその有効網目鎖濃度は 処理温度とともに低下した. 処理温度が同じ条件 で分解剂/再生オイル添加量の影響を見ると, ゲ ル成分量はほぼ一定の值であったが，有効網目鎖 濃度は添加量とともに低くなった。 またスクリュ 回転数が増加するとゲル成分量，有効網目鎖濃度 はともに大きく低下した。次にFig. 4 に種々の 処理温度で得られる再生ゴムのゾル成分の分子量 
Table 3 Properties of devulcanized rubber

\begin{tabular}{|c|c|c|c|}
\hline Test No. & $\begin{array}{l}\text { Mooney viscosity } \\
\qquad\left(\mathrm{ML}_{1+4}\right)\end{array}$ & $\begin{array}{l}\text { Gel fraction } \\
(\%)\end{array}$ & $\begin{array}{c}\text { Effective network chain } \\
\text { density of } \operatorname{gel}\left(\times 10^{-5} \mathrm{~mol} /\right. \\
\left.\mathrm{cm}^{3}\right)\end{array}$ \\
\hline 1 & 60 & 95.1 & 1.43 \\
\hline 2 & 29 & 78.7 & 0.95 \\
\hline 3 & 10 & 38.0 & 0.25 \\
\hline 4 & 24 & 85.1 & 0.63 \\
\hline 5 & 15 & 59.3 & 0.27 \\
\hline 6 & 5 & 27.3 & 0.18 \\
\hline 7 & 80 & 85.1 & 1.17 \\
\hline 8 & 67 & 56.4 & 0.48 \\
\hline 9 & 68 & - & - \\
\hline 10 & 62 & - & - \\
\hline 11 & 61 & - & - \\
\hline 12 & 72 & 66.9 & 0.40 \\
\hline 13 & 76 & 68.7 & 0.45 \\
\hline 14 & 95 & 78.0 & 1.08 \\
\hline 15 & 77 & 78.4 & 0.85 \\
\hline 16 & 71 & 88.7 & 1.43 \\
\hline 17 & 62 & 69.6 & 0.88 \\
\hline 18 & 25 & 77.4 & 0.35 \\
\hline 19 & 19 & 82.6 & 0.49 \\
\hline 20 & 16 & 66.0 & 0.33 \\
\hline 21 & 20 & 74.2 & 0.21 \\
\hline 22 & 12 & 70.9 & 0.20 \\
\hline 23 & 14 & - & - \\
\hline 24 & 80 & 85.1 & 1.17 \\
\hline 25 & 76 & 82.5 & 1.15 \\
\hline 26 & 69 & 82.5 & 1.15 \\
\hline 27 & 64 & 47.2 & 0.39 \\
\hline 28 & - & 87.0 & 1.11 \\
\hline 29 & - & 53.5 & 0.47 \\
\hline 30 & - & 24.5 & 0.19 \\
\hline $\begin{array}{l}\text { Virgin } \\
\text { compounded } \\
\text { rubber } \\
\text { Virgin }\end{array}$ & 71 & 0 & - \\
\hline $\begin{array}{l}\text { vulcanized } \\
\text { rubber }\end{array}$ & - & 100 & 9.0 \\
\hline
\end{tabular}

分布を新材の生ゴムと比較して示した，処理温度 が $300^{\circ} \mathrm{C}$ 以下では，分子量は新材の生ゴムとほぼ 同等であったが, 処理温度が $350^{\circ} \mathrm{C}$ になると分子 量が低下していることから主鎖の切断が進行して いると考えられる。

3.3 .2 再加硫ゴムの特性 再生ゴムの加硫特
性を，キュラストメーターを用いて $160^{\circ} \mathrm{C} て ゙$ 評価 した.ここでは加硫曲線のトルクの最大值から最 小值を引いたトルク上昇量を指標とした，各処理 条件でのトルク上昇量を Fig. 5 に示す. トルク 上昇量は処理温度にはほとんど依存しなかった が，分解剂/再生オイルの添加に大きく依存した. 


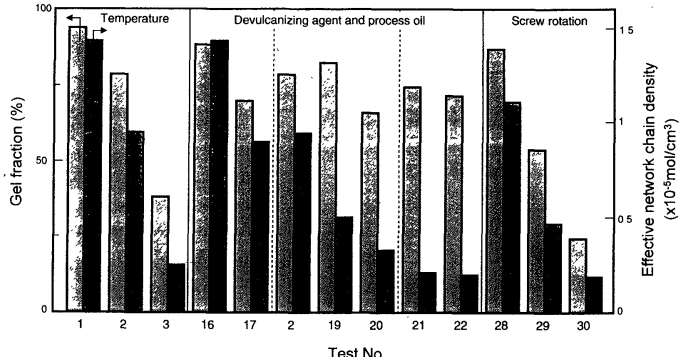

Fig. 3 Gel fraction and its effective network chain density of devulcanized rubber

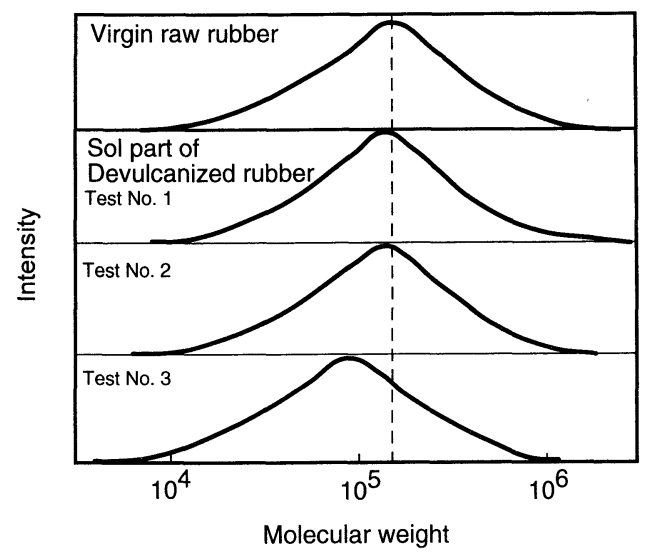

Fig. 4 Molecular weight distribution of sol part of devulcanized rubber

特に再生オイルの添加により上昇量は小さくなっ たが, 再生オイルを 30 重量部以上添加してもト ルク上昇量の変化はほとんどみられなかった。再 生オイルの添加がないと, トルク上昇量は分解剂 の添加に大きく依存し，分解剂の添加量とともに トルク上昇量が小さくなった. 再生オイルを分解 剂と同時に添加した場合には，分解剤の添加量を 増してもトルク上昇量はほとんど変化しなかっ た。無添加では，トルク上昇量は新材とほぼ同等 となった. また, Fig. 6 に示す添加量を変化させ たときの代表的な加硫曲線を見ると，分解剂/再 生オイルの添加により，トルク上昇量の低下だけ でなく，加硫時間も遅くなる傾向にあるが，無添 加ではトルク上昇量および加硫時間は新材とほぼ 同等となることがわかった。

次に再加硫ゴムの硬度, 引張強さ，破断伸びを Table 4 に示寸.そのなかから引張強さとの関係

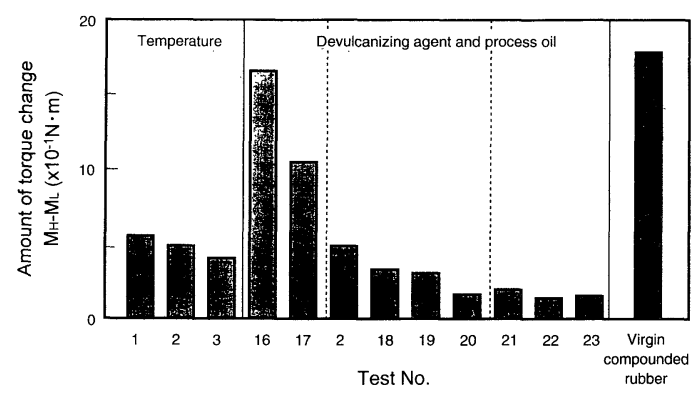

Fig. 5 Amount of torque change during revulcanization

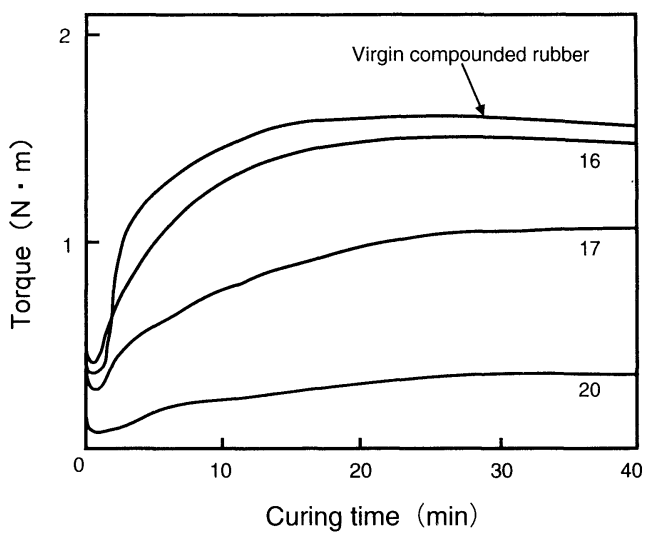

Fig. 6 Curing curves of devulcanized rubber

をまとめて Fig. 7 に示す。まず処理温度の影響 を見ると, 引張強さは, $300^{\circ} \mathrm{C}$ 前後の処理で最大 となった，更に温度を上げると引張強さは低下し た。これは前述したように高温では再生ゴムのゾ ル成分の分子量が低下しているためと考えられ る. 次に, 分解郕/再生オイルの添加量の影響を 見たところ，これらの添加により引張強さは小さ くなる傾向にあった．添加量が少量であると新材 とほぼ同等の引張強さとなった，また，スクリュ 回転数にはほとんど影響されれなかったが，低回転 側および高回転側では若干引張強さが低下する傾 向にあった。次に破断伸びについてまとめて Fig. 8 に示す，処理温度に対しては，引張強さと 同様に $300^{\circ} \mathrm{C}$ 前後の処理で最大の值となった. 分 解剂/再生オイルを添加すると伸びは引張強さと は逆に大きくなるが, 添加量が少量であると新材 とほぼ同等の伸びとなった，伸びに対するスクリ ュ回転数の影響は小さいが，高回転側で若干大き 
Table 4 Mechanical properties of revulcanized rubber

\begin{tabular}{|c|c|c|c|}
\hline Test No. & $\begin{array}{l}\text { Hardness } \\
\text { (JIS A) }\end{array}$ & $\begin{array}{l}\text { Tensile strength } \\
(\mathrm{MPa})\end{array}$ & $\begin{array}{c}\text { Elongation at break } \\
(\%)\end{array}$ \\
\hline 1 & 54 & 6.7 & 400 \\
\hline 2 & 51 & 7.7 & 480 \\
\hline 3 & 49 & 5.6 & 480 \\
\hline 4 & 43 & 4.1 & 530 \\
\hline 5 & 45 & 5.2 & 640 \\
\hline 6 & 40 & 2.3 & 530 \\
\hline 7 & 75 & 10.3 & 360 \\
\hline 8 & 75 & 10.4 & 410 \\
\hline 9 & 73 & 10.5 & 360 \\
\hline 10 & 73 & 11.7 & 370 \\
\hline 11 & 73 & 10.9 & 360 \\
\hline 12 & 74 & 8.3 & 440 \\
\hline 13 & 74 & 8.6 & 450 \\
\hline 14 & - & - & - \\
\hline 15 & - & - & - \\
\hline 16 & 81 & 11.2 & 340 \\
\hline 17 & 79 & 8.8 & 460 \\
\hline 18 & 48 & 6.4 & 470 \\
\hline 19 & 47 & 6.8 & 550 \\
\hline 20 & 41 & 4.9 & 590 \\
\hline 21 & 35 & 3.8 & 410 \\
\hline 22 & 33 & 3.7 & 490 \\
\hline 23 & 38 & 4.7 & 610 \\
\hline 24 & 75 & 10.3 & 360 \\
\hline 25 & 74 & 11.3 & 360 \\
\hline 26 & 74 & 11.1 & 370 \\
\hline 27 & 75 & 9.9 & 400 \\
\hline 28 & - & - & - \\
\hline 29 & - & - & - \\
\hline 30 & - & - & - \\
\hline $\begin{array}{l}\text { Virgin } \\
\text { vulcanized } \\
\text { rubber }\end{array}$ & 82 & 10.2 & 410 \\
\hline
\end{tabular}

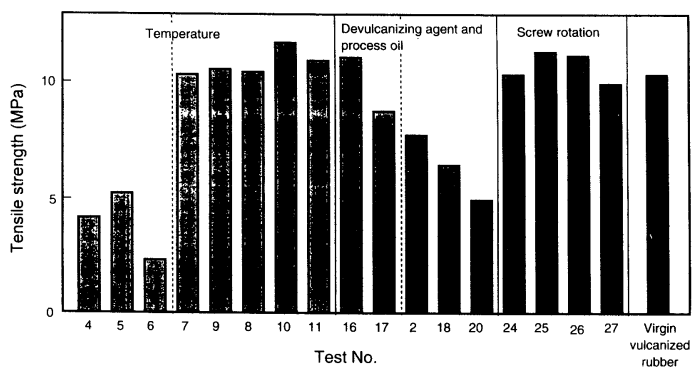

Fig. 7 Tensile strength of revulcanized rubber
くなる傾向にあった，次に分解剂/再生オイルの 添加量を変化させたときの再加硫ゴムの代表的な 応力ーひずみ曲線を Fig. 9 に示す。無添加では応 力ーひずみ曲線は新材とほぼ同等となった. 分解 剂/再生オイルを添加して脱硫反応を行うと, 引 張強さは低くなるものの破断伸びが大きくなる傾 向にあり，本技術では処理条件により再生ゴムの 物性を幅広い範囲で制御することが可能であると いえる。 


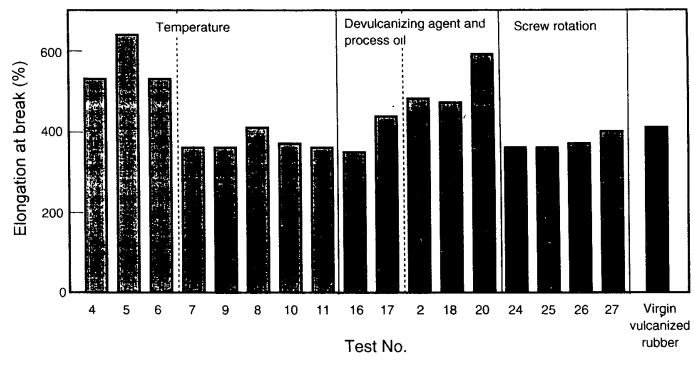

Fig. 8 Elongation at break of revulcanized rubber

\section{4.まと め}

(1)せん断流動場反応制御技術によるゴムの脱硫反 応では，高い静水圧下で，ゴムに大きなせん断変 形を与えることが重要であった。この考え方に基 づいてスクリュ形状を適切に設計することにより 連続的に再生ゴムを得ることが可能となった。

(2)再生ゴムの特性は, 処理温度, スクリュ回転 数, 分解剂/再生オイルの添加の有無および添加 量に依存していた。

(3)実験機の場合は，処理温度が $270 \sim 330^{\circ} \mathrm{C}$ ， ス クリュ回転数が 200 400 rpm で脱硫反応処理を 行うと, 分解剂/再生オイルを添加しなくても連 続的にゴムを脱硫することが可能であった．ま た，この条件で得られる再加硫ゴムの力学特性は 新材とほぼ同等であった。

(4)脱硫反応処理時に添加する分解剂/再生オイル 量を調節することにより, 再加硫ゴムの力学特性 を幅広く制御することが可能であった。

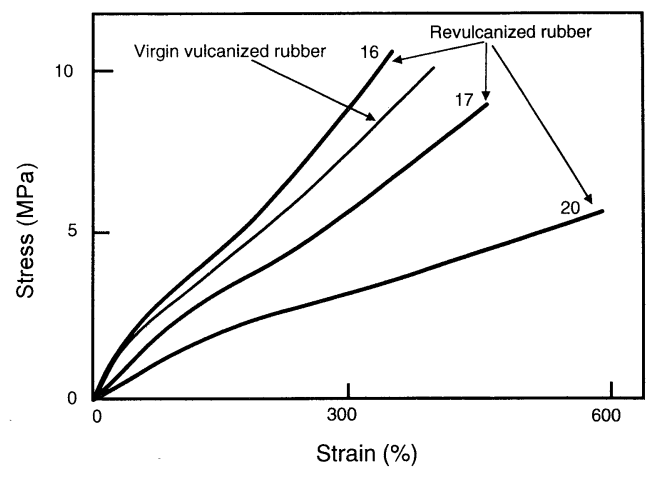

Fig. 9 Stress-strain curves of revulcanized rubber

\section{参 考 文 献}

1) 毛利誠, 佐藤紀夫, 岡本浩孝, 松下光正, 本多秀亘, 中島克己，竹内勝政，鈴木康之，大脇雅夫：日ゴム協 誌，72，50(1999)

2 ）日本ゴム協会編「ゴム試験法 新版」，210(1988)

3) Flory, P.J., Rehner, J. : J. Chem. Phys., 18, 108 (1950)

4) Flory, P.J. : J. Chem. Phys., 18, 108 (1950)

5 ）川端成彬，山下晋三：日ゴム協誌，52，256 (1979)

6）川端成彬，村上工，山下晋三：日ゴム協誌，52, $768(1979)$

7 ) Kawabata, N., Yamashita, S., Furukawa, Y. : Bull. Chem. Soc. Japan, 5, 625, (1978)

8 ) 岡本弘, 稲垣慎二, 尾之内千夫, 古川淳二：日ゴム協 誌，52，774(1979)

9 ）尾之内千夫, 稲垣慎二, 岡本弘, 古川淳二：日ゴム協 誌，53，756(1980)

10)古川淳二, 岡本弘, 稲垣慎二, 尾之内千夫, 案西司郎, 渡部洋児, 藤田寛治, 柴田慶三：日ゴム協誌，53, $497(1980)$ 